\title{
Increase in soil organic carbon by agricultural intensification in northern China
}

\author{
Y. Liao ${ }^{1,2}$, W. L. Wu ${ }^{1}$, F. Q. Meng ${ }^{1}$, P. Smith ${ }^{3}$, and R. Lal ${ }^{4}$ \\ ${ }^{1}$ College of Resources and Environmental Sciences, China Agricultural University, Beijing 100193, China \\ ${ }^{2}$ Chinese Academy of Agricultural Engineering, Beijing 100125, China \\ ${ }^{3}$ Institute of Biological \& Environmental Sciences, University of Aberdeen, 23 St Machar Drive, Aberdeen, AB24 3UU, UK \\ ${ }^{4}$ Carbon Management and Sequestration Center, The Ohio State University, 2021 Coffey Road, Columbus, OH 43210, USA \\ Correspondence to: F. Q. Meng (mengfq@cau.edu.cn)
}

Received: 20 September 2014 - Published in Biogeosciences Discuss.: 28 November 2014

Revised: 2 February 2015 - Accepted: 2 February 2015 - Published: 5 March 2015

\begin{abstract}
Agricultural intensification has contributed greatly to the sustained food supply of China's population of 1.3 billion over the 30-year period from 1982 to 2011. Intensification has several and widely recognized negative environmental impacts including depletion of water resources, pollution of water bodies, greenhouse gas emissions and soil acidification. However, there have been few studies over this period on the impacts of intensification on soil organic carbon (SOC) at the regional level. The present study was conducted in Huantai County, a typical intensive farming region in northern China, to analyze the temporal dynamics of SOC influenced by climate and farming practices. The results indicate that from 1982 to 2011, SOC content and density in the $0-20 \mathrm{~cm}$ layer of the cropland increased from $7.8 \pm 1.6$ to $11.0 \pm 2.3 \mathrm{~g} \mathrm{~kg}^{-1}(41 \%)$ and from $21.4 \pm 4.3$ to $33.0 \pm 7.0 \mathrm{Mg} \mathrm{ha}^{-1}(54 \%)$, respectively. The SOC stock $(0-20 \mathrm{~cm})$ of the farmland for the entire county increased from 0.75 to $1.2 \mathrm{Tg}(59 \%)$. Correlation analysis revealed that incorporation of crop residues significantly increased SOC, while an increase in the mean annual temperature decreased the SOC level. Therefore, agricultural intensification has increased crop productivity and contributed to SOC sequestration in northern China. In the near future, more appropriate technologies and practices must be developed and implemented for a maintenance or enhancement of SOC in this region and elsewhere in northern China, which also reduce non- $\mathrm{CO}_{2}$ greenhouse gas emissions, since the climate benefit from the additional SOC storage is estimated to be smaller than the negative climate impacts of $\mathrm{N}_{2} \mathrm{O}$ from $\mathrm{N}$ fertilizer additions.
\end{abstract}

\section{Introduction}

Increasing soil organic matter (SOM) storage in arable lands can ensure the sustained supply of nitrogen $(\mathrm{N})$ and other nutrients to crop growth and maintain appropriate soil quality such as aeration, permeability, water-holding capacity and nutrient preserving capacity (Smith et al., 2012). Globally, accumulation of SOM or soil organic carbon (SOC) stock in arable lands, which contribute to the mitigation of greenhouse effect and a concomitant improvement in soil fertility (Matson et al., 1997; Sainju et al., 2009), may be achieved by a range of improved farming practices. These practices include adoption of high-yielding crop varieties, balanced fertilization, crop residue incorporation, no-till (NT) or reduced tillage, optimal irrigation, high cropping intensity (Matson et al., 1997; Kucharik, et al., 2001). For instance, agricultural soils in the USA had a carbon sink capacity of from 1.3 to $21.2 \mathrm{Tg} \mathrm{C}$ annually from 1982 to 1997 , due to land use, NT, higher cropping intensity, etc. (Eve et al., 2002; Ogle et al., 2003). The rate of increase in SOC stock in Canada was $5.7 \mathrm{Tg} \mathrm{C} \mathrm{yr}^{-1}$ from 1991 to 2001 (Vanden Bygaart et al., 2004). In the Netherlands, the SOC content of arable land increased by about $0.08 \mathrm{~g} \mathrm{~kg}^{-1} \mathrm{yr}^{-1}$ between 1984 and 2004 (Reijneveld et al., 2009). Benbi and Brar (2009) reported that SOC in the Punjab state of India increased from 2.9 to $4.0 \mathrm{~g} \mathrm{~kg}^{-1}(38 \%)$ between 1981 and 2006, largely resulting from irrigation, optimal fertilization, and an increase in crop productivity.

Northern China is one of the most important agricultural regions, producing $60-80 \%$ and $35-40 \%$ of nation's wheat (Triticum aestivum L.) and maize (Zea mays L.), respectively 
(NBSC, 2014). Similar to other regions in northern China, Huantai County has experienced the agricultural intensification process including a high cropping intensity (200\%, winter wheat-summer maize), high fertilizer rate $(500-600 \mathrm{~kg}$ $\mathrm{Nha}^{-1} \mathrm{yr}^{-1}$ ), frequent irrigation and tillage, and an increasing ratio of crop residues incorporation since the 1980s (Shi et al., 2013; Kong et al., 2014). Agricultural intensification increased crop yield within a short period. For example, Huantai County has achieved a production of $>15 \mathrm{Mg}$ of grain (wheat + maize) $\mathrm{ha}^{-1} \mathrm{yr}^{-1}$ for all of its farmland since 1990. The effect of agricultural intensification on increasing crop yields has been well documented; however, most of the research done on SOC sequestration in agricultural soils is confined to long-term plot-scale experiments. Studies available at national or region levels were within short periods, especially in northern China ( $<20$ years) which is characterized by low levels of SOM.

We collected 3 decades of data of climate, farm management and crop yield from Huantai County to (1) analyze the evolution of SOC at the regional level from 1982 to 2011 and (2) establish the cause-effect relationship between the driving forces and SOC change. The results derived from this study may contribute to improved farm management for the long-term sustainable agricultural development in the intensive farming of northern China and elsewhere.

\section{Materials and methods}

\subsection{Study area}

Huantai County, with an area of $509 \mathrm{~km}^{2}$, is located in northern China $\left(36^{\circ} 51^{\prime} 50^{\prime \prime}-37^{\circ} 06^{\prime} 00^{\prime \prime} \mathrm{N}, 117^{\circ} 50^{\prime} 00^{\prime \prime}-\right.$ $\left.118^{\circ} 10^{\prime} 40^{\prime \prime} \mathrm{E}\right)$. It is characterized by a warm temperate continental monsoon climate, with an annual average temperature of $13.4^{\circ}$ and annual precipitation of $604 \mathrm{~mm}$. The rainfall occurs mainly in June, July and August, with the annual frostfree season of about 198 days. The slope gradient of the landscape is low in northern and high in southern regions, with an average altitude of $6.5-29.5 \mathrm{~m}$, falling gently from the southwest to northeast. The main soil types, according to the US soil classification system, include Haplustalfs, Aquents and Vertisols. The household contract responsibility system was implemented in Huantai County in 1980, and land productivity has increased significantly with an increase in fertilizer input, frequent irrigation and adoption of high-yielding varieties. In 1990, Huantai County became the first Dun Liang County which achieved high productivity of 1 ton of grain per "mu" for the whole county ( $1 \mathrm{mu}=1 / 15 \mathrm{ha})$ in China. Vegetable production has also been intensified in the county since 1990s.

\subsection{Data collection}

The soil, climate and farming data were collected between 2011 and 2013 from the sources as described below:
- The second National Soil Survey: the second National Soil Survey in China was conducted from 1981 to 1983 , and was undertaken in 1982 for Huantai County. The survey collected and analyzed soil samples for genesis, physical, chemical and biological properties. The SOM content was tested using the potassium dichromate titrimetric method (Jankauskas et al., 2006). The SOM data in this study were obtained for 258 soil samples (0$20 \mathrm{~cm}$ ), together with the corresponding GPS location coordinates.

- Annual Soil Fertility Survey: the annual SOM data of farmland soil $(0-20 \mathrm{~cm})$ were collected from the annual Soil Fertility Survey, a program which has been undertaken by the county agricultural extension services every year since 1987 . Every year, samples from the topsoil layer were collected after the autumn harvest and analyzed for $\mathrm{pH}$, SOM and nutrient contents. Soil sampling in the survey was stratified according to the division of administrative villages. Each village had at least one composite soil sample, representing 6.7-33.3 ha of farmland. The number of soil samples was from 199 (in 2003 ) to 3637 (in 2007) and the average was 786 each year. The SOM content was determined by the potassium dichromate titrimetric method (Jankauskas et al., 2006). The data for 1988, 1991, 2000, 2001, 2004, 2005 and 2010 were for each town as the survey was only done at the township level. As there were no data for the period 1983 to 1986 , it was assumed that a steady change in SOC occurred during this period. Thus, the average SOC content for the whole county was obtained by interpolation based on the data from 1982 and 1987.

- Soil Sampling and Measurement Program: in September 2011, a soil survey was implemented for the whole county. Soil samples were obtained from 0-20 cm depth in farmland which includes cropland (for winter wheat and summer maize production) and Land used for vegetable cultivation, in an evenly distributed $2 \times 2 \mathrm{~km}$ grid. Each sample was composited from three collection points. The GPS location was recorded for each sampling point. Soil was ground and passed through a $0.15 \mathrm{~mm}$ sieve. For the SOC analysis, $2-3 \mathrm{~g}$ of the soil sample was placed into the beaker, and then $20 \mathrm{~mL} \mathrm{HCl}$ of $0.5 \mathrm{~mol} \times \mathrm{L}^{-1}$ was added for acidification and removal of carbonates. Samples were then transferred into a rotary oscillator (Ronghua, HY-B) to shake for $30 \mathrm{~min}$. After standing for $12 \mathrm{~h}$, deionized water was used to remove the acid from soil samples until neutral $\mathrm{pH}$ was obtained. Soil samples were dried in the oven at $60^{\circ}$ and weighed. The SOC content was determined by a $\mathrm{C}$ and N Elemental Analyzer (Thermo Flash EA 1112). 
As acidification led to soil mass loss, the SOC data were corrected using Eq. (1):

$W_{\text {soil2 }}=\frac{m_{\text {soil1 }} \times W_{\text {soil1 }}}{m_{\text {soil2 }}}$,

where $W_{\text {soil2 }}$ is the corrected SOC content, $m_{\text {soill }}$ is the soil mass after acidification, $W_{\text {soill }}$ is the SOC content after acidification and $m_{\text {soil } 2}$ is the soil mass before acidification. The comparative study of SOC content determined by elemental analyzer and potassium dichromate titrimetric method indicated that these two methods are comparable and the differences between them are not significant (Wang et al., 2014).

- Climate and farm management: data were obtained for land use (e.g., areas for growing winter wheat, summer maize, vegetables and urban use), grain and straw yields of wheat and maize, nitrogen fertilizer rate and the rate of straw incorporation from the Huantai agricultural yearbook of 1982-2011. Climate data for temperature and precipitation were obtained from the China Climatic Data Center, National Meteorological Information Center, CMA (http://cdc.cma.gov.cn). The temperature and precipitation data were daily values for the county level.

- Calculation of SOC density and stock: the Van Bemmelen conversion factor, namely that SOM contains $58 \%$ carbon (Page et al., 1982), was used to compute SOC content in (Eq. 2). The SOC density and stock were computed by Eqs. (3) and (4), respectively:

$\mathrm{SOC}=\mathrm{SOM} \times 0.58 \times 10$,

$\mathrm{SOCD}=\mathrm{SOC} \times \gamma \times H \times 10^{4}$,

SOCS $=$ SOCD $\times S \times 10^{-9}$,

where SOC is the soil organic carbon content $\left(\mathrm{g} \mathrm{kg}^{-1}\right)$, SOM is the soil organic matter content (\%), SOCD is the SOC density $\left(\mathrm{kg} \mathrm{ha}^{-1}\right), \gamma$ is the soil bulk density (BD, $\left.\mathrm{g} \mathrm{cm}^{-3}\right), H$ is the thickness (m) of soil layer $(0-20 \mathrm{~cm})$, SOCS is the SOC stock ( $\mathrm{Tg}$ ) for the whole county and $S$ is the farmland area (ha). Soil BD values were interpolated over the years from measured values taken in 1982 and 2011. The average number of samples from crop land and land used for vegetable cultivation was 786 and 79, respectively. For the calculation of SOCS, we assumed that the SOC content of Land under construction (being converted to urban or industrial land use types) was maintained at the same level after the farmland was converted.

\subsection{Data analysis}

The Kolmogorov-Smirnov test was used in the SPSS Statistics 17.0 package to determine if SOC content followed

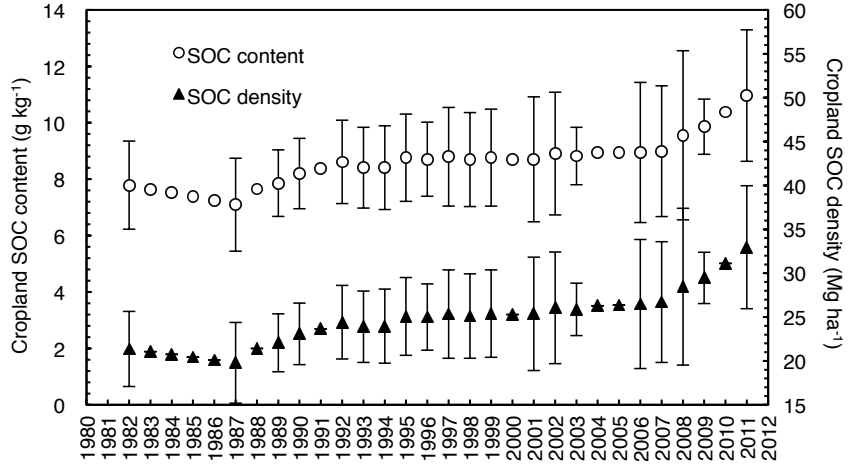

Figure 1. Evolution of SOC content and density for cropland from 1982 to 2011 in Huantai County. Error bars are shown only for the years which soil survey is undertaken.

a normal distribution. Central tendency, dispersion degree and distribution characteristics of SOC data were calculated. Pearson correlation analysis and/or partial correlation analysis were conducted between SOC content and driving factors including mean annual temperature, mean annual precipitation, grain yield, nitrogen fertilizer rate and straw $\mathrm{C}$ incorporation. A multivariate regression model was developed to account for the impact of these factors on temporal SOC change in Huantai County.

\section{Results}

\subsection{Evolution of SOC content and density between 1982 and 2011}

Figure 1 presents the dynamic changes of topsoil SOC content and density for the cropland (winter wheat-summer maize) from 1982 to 2011. The mean increase in cropland from 1982 to 2011 was from $7.8 \pm 1.6$ to $11.0 \pm 2.3 \mathrm{~g} \mathrm{~kg}^{-1}$ for SOC content and from $21.4 \pm 4.3$ to $33.0 \pm 7.0 \mathrm{Mg} \mathrm{ha}^{-1}$ for SOC density, with rates of increase of 41 and $54 \%$, respectively. The mean SOC content of land used for vegetable cultivation increased similarly to cropland, i.e., from $7.8 \pm 1.6$ to $11.0 \pm 2.8 \mathrm{~g} \mathrm{~kg}^{-1}$ (data not shown). This trend indicates that the rate of increase in SOC content and density of cropland $(0-20 \mathrm{~cm})$ in Huantai County since the early $1980 \mathrm{~s}$ has been $0.11 \mathrm{~g} \mathrm{~kg}^{-1} \mathrm{yr}^{-1}$ and $0.40 \mathrm{Mg} \mathrm{ha}^{-1} \mathrm{yr}^{-1}$, respectively. The growth of SOC density is significantly related to increasing SOC content, but is also supported by the increase in soil BD in the $0-20 \mathrm{~cm}$ layer of the farmland $\left(1.4 \mathrm{~g} \mathrm{~cm}^{-3}\right.$ in 1982 to $1.5 \mathrm{~g} \mathrm{~cm}^{-3}$ in 2011).

\subsection{Change of SOC stock in Huantai County from 1982 to 2011}

An adjustment in the local agricultural sector altered the land use between 1982 and 2011 in Huantai County. The farmland area in 1982 was 35204 ha, of which more than $99 \%$ was 


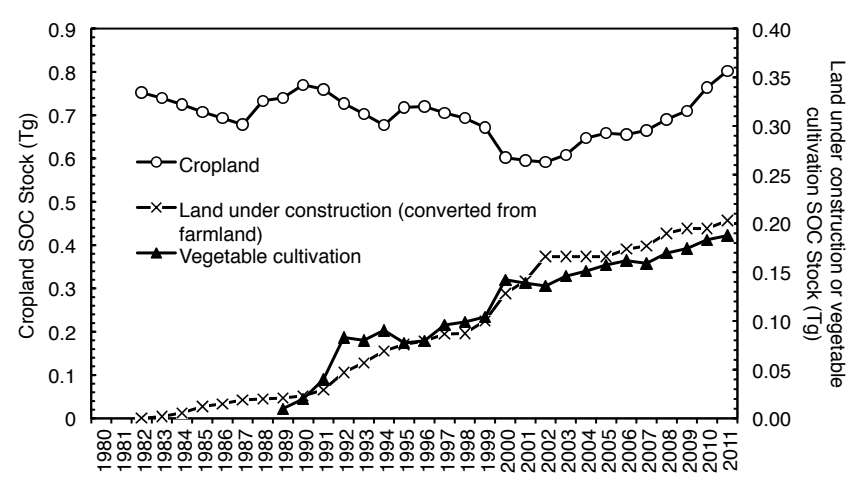

Figure 2. Change of SOC stock for farmland (cropland, vegetable land, farmland converted to construction land) from 1982 to 2011 in Huantai County.

winter wheat-summer maize cropping (cropland). Due to the expansion of vegetable production starting in the 1990s, land used for vegetable production increased to about $20 \%$ by the early 2000s, and has remained constant through 2011 at about 6000 ha. The average SOC content of vegetable land is not significantly different from that of cropland (11.0 vs. $11.0 \mathrm{~g} \mathrm{~kg}^{-1}$ in 2011 for the whole county). Some farmland was converted to construction land (urban or industrial land use types). Of the $31 \%$ reduction of farmland area between 1982 and 2011, $16 \%$ was used for vegetable farming and $15 \%$ converted to construction land.

Although cropland area decreased from 35204 ha in 1982 to $24343 \mathrm{ha}$ in 2011 , the SOC stock of cropland $(0-20 \mathrm{~cm})$ increased from $0.75 \pm 0.15$ to $0.80 \pm 0.17 \mathrm{Tg} \mathrm{C}$ (an increase by $6.7 \%$, Fig. 2). When the SOC stock in vegetable land and construction land (converted from cropland; the area increased every year as urbanization took place) was also included, total SOC stock of the farmland in the Huantai County was estimated to be $1.2 \mathrm{Tg} \mathrm{C}$ in 2011 , with a total increase of $59 \%$ compared to $0.75 \pm 0.15 \mathrm{Tg} \mathrm{C}$ in 1982 (Fig. 2).

\subsection{The cause-effect relationship governing change in SOC level}

Among the natural/climate forces which can influence SOC level, mean air temperature in Huantai County increased within the period of 1982-2011, with a relationship represented by the regression equation $y=0.073 x+12.2\left(R^{2}=\right.$ $0.67, P<0.0001$, Fig. 3a). However, there was no significant change in precipitation over this period. Nitrogen fertilizer input for farmland was $400 \mathrm{~kg} \mathrm{~N} \mathrm{ha}^{-1} \mathrm{yr}^{-1}$ in the $1980 \mathrm{~s}$ and peaked at about $600 \mathrm{~kg} \mathrm{~N} \mathrm{ha}^{-1} \mathrm{yr}^{-1}$ in 1994 , followed by a decline to $500 \mathrm{~kg} \mathrm{~N} \mathrm{ha}^{-1} \mathrm{yr}^{-1}$ in 2011 . There were also significant increases in grain yield over this period $\left(R^{2}=0.63\right.$, $P<0.0001$, Fig. 3b). The carbon input between 1982 and 1987 was estimated at about 800 to $1000 \mathrm{~kg} \mathrm{Cha}^{-1} \mathrm{yr}^{-1}$, mainly through roots. However, crop production experienced
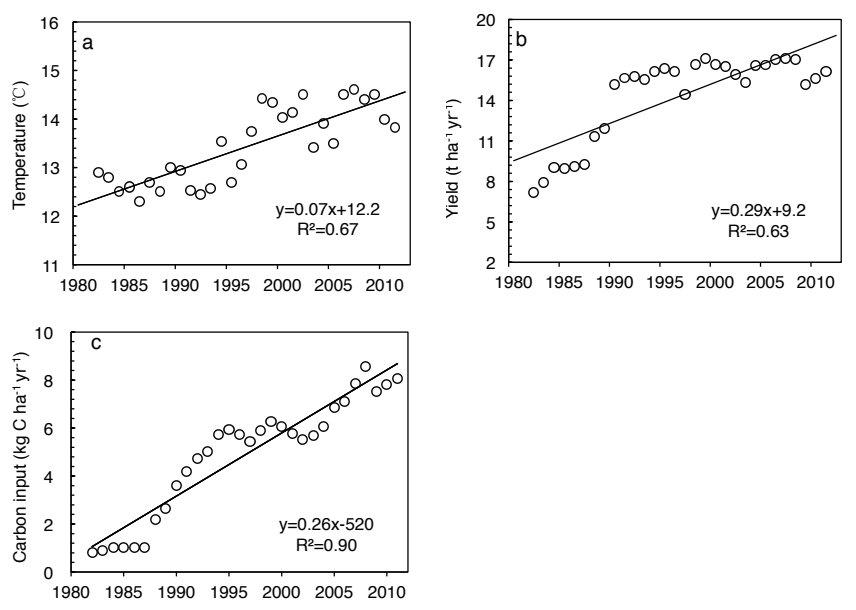

Figure 3. Regression analysis of driving factors with the years in Huantai. (a) temperature vs. year, (b) yield vs. year and (c) carbon input vs. year.

a rapid growth after 1988, and crop residues (mainly wheat straw) were returned to the soil, leading to a significant increase in the input of biomass $\mathrm{C}$, especially the aboveground C. As much as $70 \%$ of maize straw was also incorporated to the farmland from 2007 onward, leading to a total $\mathrm{C}$ input of $>8000 \mathrm{~kg} \mathrm{ha}^{-1} \mathrm{yr}^{-1}\left(R^{2}=0.90, P<0.0001\right.$, Fig. $\left.3 \mathrm{c}\right)$.

Correlation and regression analyses were performed between SOC of cropland and driving factors, i.e., temperature, precipitation, crop (wheat and maize) yield, $\mathrm{N}$ fertilizer rate and $\mathrm{C}$ input from crop residues (Table 1). There was a highly significant correlation $(P<0.01)$ between SOC content and temperature, crop yield and $\mathrm{C}$ input from crop residues, with correlation coefficients $(r)$ of $0.55,0.79$ and 0.91 , respectively. The correlation between SOC and $\mathrm{N}$ fertilizer rate was also significant $(r=0.38, P<0.05$ ). However, there was no significant correlation between SOC content and mean annual precipitation.

A partial correlation analysis was conducted to determine the relationship between SOC content of cropland and any major driving factor, as the effect of a set of controlling random variables was removed (Table 2). The data indicated a highly significant and positive correlation between SOC content and the $\mathrm{C}$ input from crop residues $(r=0.80$, $P<0.0001)$, but a negative correlation between SOC content and annual mean temperature $(r=-0.42, P=0.027)$. The weak positive correlation between SOC content and N fertilizer rate $(r=0.03, P=0.86)$, and weak negative correlation between SOC and crop yield $(r=-0.08, P=0.70)$, indicated that $\mathrm{N}$ fertilizer and increasing crop yield did not contributed to the augmentation of SOC in Huantai from 1982 to 2011. As the effect of $\mathrm{C}$ input from crop residues was removed during partial correlation, the rising temperature during the past 3 decades significantly decreased the cropland SOC content in Huantai, or promoted the SOC de- 
Table 1. Correlation analysis between SOC content of cropland and driving factors in Huantai County.

\begin{tabular}{|c|c|c|c|c|c|c|}
\hline & SOC & Temperature & Precipitation & $\begin{array}{l}\text { Crop } \\
\text { yield }\end{array}$ & $\begin{array}{c}\mathrm{N} \\
\text { fertilizer } \\
\text { rate }\end{array}$ & $\begin{array}{l}\mathrm{C} \text { input } \\
\text { from crop } \\
\text { residues }\end{array}$ \\
\hline $\mathrm{SOC}$ & 1 & & & & & \\
\hline Temperature & $0.55^{\mathrm{a}}$ & 1 & & & & \\
\hline Precipitation & 0.30 & 0.09 & 1 & & & \\
\hline Crop yield & $0.79^{\mathrm{a}}$ & $0.62^{\mathrm{a}}$ & 0.30 & 1 & & \\
\hline $\mathrm{N}$ fertilizer rate & $0.38^{\mathrm{b}}$ & 0.01 & $0.48^{\mathrm{a}}$ & $0.55^{\mathrm{a}}$ & 1 & \\
\hline $\begin{array}{l}\mathrm{C} \text { input from } \\
\text { crop residues }\end{array}$ & $0.91^{\mathrm{a}}$ & $0.73^{\mathrm{a}}$ & 0.35 & $0.89^{\mathrm{a}}$ & $0.43^{\mathrm{b}}$ & 1 \\
\hline
\end{tabular}

a means a highly significant correlation at the level of $P<0.01 .{ }^{\mathrm{b}}$ means a significant correlation at the level of $P<0.05$.

Table 2. Partial correlation analysis between SOC content of cropland and driving factors in Huantai County.

\begin{tabular}{lll}
\hline Control variables & $\begin{array}{l}\text { Partial correlation coefficient between SOC and } \\
\text { the driving factor* }\end{array}$ & \\
\hline $\begin{array}{l}\text { Crop yield, C input from } \\
\text { crop residues }\end{array}$ & SOC vs. Temperature & $-0.42(P=0.03, \mathrm{~d} f=26)$ \\
$\begin{array}{l}\text { Crop yield, C input from } \\
\text { crop residues }\end{array}$ & $\begin{array}{l}\text { SOC vs. N fertilizer } \\
\text { rate }\end{array}$ & $0.03(P=0.86, \mathrm{~d} f=26)$ \\
$\begin{array}{l}\text { C input from crop residues, } \\
\text { N fertilizer rate, Temperature } \\
\text { Crop yield }\end{array}$ & SOC vs. Crop yield & $-0.08(P=0.70, \mathrm{~d} f=25)$ \\
\hline
\end{tabular}

* All of the partial correlation coefficients are two-tailed.

composition. In addition to the partial correlation analysis, a multivariate regression model was also developed as follows:

$Y=12.0-0.31$ Temperature -0.0003 Precipitation 0.0006 Nitrogen $+0.0005 \mathrm{C}$ input -0.0001 Yield $\left(R^{2}=\right.$ 0.88 ), where, $Y$ is the SOC content in $\mathrm{g} \mathrm{kg}^{-1}$. The multivariate regression analysis also confirmed the positive impact of the input of crop residue carbon and negative impact of the increase in temperature.

\section{Discussion}

\subsection{Driving factors for SOC accumulation}

The SOC level of farmland was influenced by climate (mainly temperature and precipitation) and farming practices, including crop residue incorporation, $\mathrm{N}$ fertilizer use, crop yield, etc. (Khan et al., 2007; Ladha et al., 2011).

Climate factors: climate warming may increase the rate of SOM decomposition, while the effect of precipitation on SOC is mostly known to be positive because in general SOC increases with increase in precipitation (Post et al., 1982). Whereas air temperature in the Huantai region has significantly increased since the 1980 s, precipitation has not. There is a significant positive correlation between the temperature and SOC content (Table 1), however the partial correlation analysis showed that the correlation was negative ( $r=-0.42, P=0.03$, Table 2$)$, indicating that SOC in Huantai County was enhanced by factors other than temperature and precipitation. Indeed, it may take much longer $(\sim 50$ years) to observe the effect of climate change on SOC level (De Bruijn et al., 2012), indicating a strong need for longterm research.

Nitrogen fertilizer: in general, $\mathrm{N}$ is the most limiting nutrient in crop production systems (Robertson and Vitousek, 2009). It promotes the production of crop dry matter (and therefore $\mathrm{C}$ input to the soil) while chemically stabilizing $\mathrm{C}$ in the soil, thereby potentially increasing soil $\mathrm{C}$ storage (Paustian et al., 1997). A high input of $\mathrm{N}$ fertilizer was a prominent feature of farming in Huantai County, where the average $\mathrm{N}$ fertilizer rate increased from $400 \mathrm{~kg} \mathrm{~N} \mathrm{ha}^{-1} \mathrm{yr}^{-1}$ in the $1980 \mathrm{~s}$ to $600 \mathrm{~kg} \mathrm{~N} \mathrm{ha}^{-1} \mathrm{yr}^{-1}$ in the $1990 \mathrm{~s}$. However, the rate of $\mathrm{N}$ fertilizer gradually declined and stabilized at $500 \mathrm{~kg} \mathrm{~N} \mathrm{ha}^{-1} \mathrm{yr}^{-1}$ in the 2010s. Such a trend is attributed to the increased use of machinery in agriculture and the extension of formula fertilization techniques adopted in the region. The strategy was to balance the $\mathrm{N}$ fertilization rate in consideration of the high grain output $(>15 \mathrm{Mg}$ grain $\mathrm{ha}^{-1} \mathrm{yr}^{-1}$ ). However, the rate of SOC increase was still high 
during this period, as indicated by a weak positive correlation between $\mathrm{N}$ fertilizer rate and SOC level over the 30year period (Table 1). The vegetable production in Huantai County is open-field and there is less organic fertilizer input (3-5 $\mathrm{Mg} \mathrm{ha}^{-1} \mathrm{yr}^{-1}$ ) compared with other regions in China like Shouguang ( $>15 \mathrm{Mg} \mathrm{ha}^{-1} \mathrm{yr}^{-1}$ ); SOC increase due to organic fertilizers is not significant and at the same level as cropland (11.0 vs. $10.9 \mathrm{~g} \mathrm{~kg}^{-1}$ in 2011).

A few studies (Khan et al., 2007; Mulvaney et al., 2009) have reported that even the long-term input of a massive amount of residue $\mathrm{C}$ and synthetic $\mathrm{N}$ fertilizer do not sequester SOC; this was not the case with the intensification of cropland in northern China. A major factor lies in the concentration of the principal parameter (i.e., SOM) which was significantly lower in cropland soils of northern China than those of the US Corn Belt ( 9 vs. $25 \mathrm{~g} \mathrm{~kg}^{-1}$, Ludwig et al., 2011) or countries of western Europe, because large areas of farmlands in northern China were affected by saline-alkaline processes prior to the 1970s. The initial low crop productivity in the temperate region where $\mathrm{N}$ fertilization rate was low resulted in higher SOC level in northern China with increasing biomass input achieved by higher input of N. Similar trends have been reported by other studies from around the world (Song et al., 2005; Alvarez, 2005). Nonetheless, it is important to point out that any excessive application of mineral $\mathrm{N}$ not only increases the production cost, but also exacerbates negative environment effects, including nitrate contamination of ground and surface waters and $\mathrm{N}_{2} \mathrm{O}$ emissions into the atmosphere (Triberti et al., 2008). Carbon sequestration effects should be valued in a systematic approach (Wang and Cao, 2011). Indeed, the climate benefit from the additional SOC storage is smaller than the climate damage caused by $\mathrm{N}_{2} \mathrm{O}$ from $\mathrm{N}$ fertilizer additions $\left(\mathrm{N}_{2} \mathrm{O}\right.$ emissions are estimated (conservatively) to be $57000 \mathrm{Mg} \mathrm{CO}_{2} \mathrm{eq} \mathrm{yr}^{-1}$, assuming the smallest farmland area of 24343 ha and current stable $\mathrm{N}$ application rate of $500 \mathrm{~kg} \mathrm{~N} \mathrm{ha}^{-1} \mathrm{yr}^{-1}$ using the IPCC Tier 1 default emission factor of 0.01 ; soil $\mathrm{C}$ storage over the period is equivalent to $54000 \mathrm{Mg} \mathrm{CO}_{2} \mathrm{eq} \mathrm{yr}^{-1}$ ). If the indirect emissions (ammonia volatilization, leaching and runoff) are considered, the environmental effect of nitrogen fertilizer application will be more serious.

Balanced fertilization should be widely promoted for optimization of the integrated economic benefits and ecosystem services. It is important to understand that increasing the input of $\mathrm{N}$ fertilizer increased SOC only when crop residues were returned to the soil. There may have been either no or only a slight increase in SOC level if the aboveground crop residues were removed or burnt (Alvarez, 2005); therefore, $\mathrm{N}$ fertilization in itself is not a suitable strategy to increase SOC, particularly considering the overriding effects of $\mathrm{N}_{2} \mathrm{O}$ emissions from the $\mathrm{N}$ fertilizer.

Grain yield: grain yield in Huantai County increased from $7200 \mathrm{~kg} \mathrm{ha}^{-1} \mathrm{yr}^{-1}$ in 1982 to $16117 \mathrm{~kg} \mathrm{ha}^{-1} \mathrm{yr}^{-1}$ in 2011 (an increase of $124 \%$ ). The highly significant correlation $(r=0.79, P<0.01)$ between SOC content and grain yield indicates the importance of SOM in achieving high crop productivity, and vice versa (Pan et al., 2009). Indeed, the interdependence between crop yield and SOM content is widely recognized (Lal, 2002, 2013). An increase in the SOC pool of $1 \mathrm{Mg} \mathrm{Cha}{ }^{-1}$ in the root zone can increase annual food production by $30-50$ million tons in developing countries (Lal, 2013). Metaanalysis indicated that crop yield greatly increased with crop residue retention $(P<0.001)$, particularly in upland China (Liu et al., 2014). Qiu et al. (2009) estimated that for every increase of $1 \mathrm{~g} \mathrm{C} \mathrm{kg}^{-1}$ of SOC in Huantai County, grain yield could increase by $454 \mathrm{~kg} \mathrm{ha}^{-1}$. The beneficial effects of crop yield increase will be enhanced as the strategy of returning crop residues and extended to other regions of northern China.

Carbon input from crop residues: carbon input is one of the most efficient factors for the accretion of SOC, which is also confirmed by the highly significant correlation between SOC content and $\mathrm{C}$ input from crop residue incorporation $(r=0.80, P<0.0001$, Table 2$)$. Similar results have also been reported by other scientists (Freibauer et al., 2004). Smith et al. $(2005,2012)$ reported that input of crop residues could attain the highest rate of $\mathrm{C}$ sequestration $\left(0.7 \mathrm{MgChayr}^{-1}\right)$ in comparison with that of merely $0.2 \mathrm{Mg} \mathrm{Cha}^{-1} \mathrm{yr}^{-1}$ with the input of mineral $\mathrm{N}$ fertilizer. In our study, there are two SOC increase stages, one early (1987-1992) and one late (2007-2012), which the early one coincides nicely with increased wheat residue incorporation and the late one with the increased maize residue incorporation. Again, it highlights the significance of crop straw input for the building of soil organic matter. In comparison with data from other countries like India $\left(\sim 1 \mathrm{Mg} \mathrm{Cha}^{-1} \mathrm{yr}^{-1}\right.$, Srinivasarao et al., 2014) or the USA ( $\sim 4.2 \mathrm{Mg} \mathrm{Cha}^{-1} \mathrm{yr}^{-1}$, Johnson et al., 2006), the input of residue $\mathrm{C}$ in northern China is much higher $\left(\sim 8 \mathrm{Mg} \mathrm{Cha}^{-1} \mathrm{yr}^{-1}\right.$, Fig. 3c) to maintain a rapid rate of increase of SOM. Thus, the rate of input of residue $\mathrm{C}$ is the principal determinant of the rate of increase of SOM (the annual rate of SOM increase being lower in India, intermediate in the USA and higher in the North China Plains). Since retention of the entire amount of residues of maize in northern China started in 2007/2008, the accretion of SOC is projected to continue for another 2 to 3 decades until the mid-2040s. It should also be noted that in our study, soil bulk density from 1983 to 2011 was interpolated, and this could give rise to errors in the SOC storage estimation.

Miao et al. (2011) reported the significance of $\mathrm{N}$ fertilizer and crop residues incorporation to the maintenance and increase of the SOM. Retention of residues (wheat and maize) in conjunction with the appropriate rate of $\mathrm{N}$ fertilization have been properly implemented in northern China where the antecedent levels of SOM are much lower than those in North America and western Europe. Therefore, a reasonable continuation of these practices will continue to accumulate SOM for a long time to come. However, similar trends may not occur under all situations. For example, Khan et al. (2007) explained that after attaining a steady state, it is 
unlikely that SOC will continue to increase, and may even decline with continuous use of synthetic $\mathrm{N}$ because of the enhanced activities of heterotrophic soil microorganisms in using crop-derived residues or SOM. In the context of northern China, therefore, it is likely that the increase in SOC level will continue because of the improved crop productivity and retention of crop residues, but it will eventually attain a new equilibrium. Some other SOC-enhancing practices including application of residue-based animal manure derived from the same land unit contribute further to SOC sequestration. In addition, higher levels of mechanization during the agricultural intensification process may increase the soil BD (about $7 \%$ in our study), and this also contributed to the increase of SOC stock and should not be ignored when quantifying of farmland carbon sequestration.

\subsection{Comparison of SOC accretion through agricultural intensification in different regions of China}

Agriculture in China has grown rapidly over the 3 decades since 1982, primarily because of the household contract responsibility system and adoption of the reform and open policy by the central government. Further, the intensification process has achieved some economic and environmental benefits (Firbank et al., 2013). In the case of northern China, however, there were also problems with increases in soil compaction and water pollution over the last 3 decades.

Among all agronomic regions, northern China registered the highest rate of SOC sequestration. In contrast, however, the SOC level has declined in northeast China since the 1980s (Table 3). Northeast China, one of the few world regions characterized by the black soil (Phaeozems) and cold climate, has high antecedent SOC content $\left(\sim 20 \mathrm{~g} \mathrm{~kg}^{-1}\right.$ in uncultivated soils). There, cultivation and intensive farming since the 1980s have increased the rate of decomposition of SOM along with a low input of organic materials and biomass $\mathrm{C}$. The SOC level in northern China was extremely low $\left(5-10 \mathrm{~g} \mathrm{~kg}^{-1}\right)$ in comparison with the soils of northeast China and other regions. This trend can be explained by the fact that northern China has a long history of low crop productivity, long dry season (Stockmann et al., 2013), sandy soil texture and low input of organic amendments. Application of $\mathrm{N}$ fertilizer and retention of crop residues has increased the SOC level more in the dry lands of northern China than in those of paddy soils of the lowlands (Liu et al., 2014). Huantai County and other agronomic regions (except northeast China) in China also witnessed increases in SOC level, mainly attributed to the practices of fertilization (synthetic and organic), increase in crop yield, retention of crop residues, adoption of conservation tillage and use of organic amendments (Table 3 ). The $0-30 \mathrm{~cm}$ layer of soils of cropland in China have gained SOC at the rate of $17-28 \mathrm{Tg} \mathrm{C} \mathrm{yr}^{-1}$ between 1980 and 2000 (Huang et al., 2010), which is similar

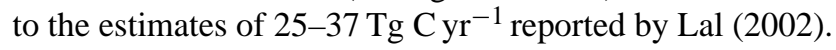

Agricultural intensification in China is an ongoing process, and is progressively evolving over time. For instance, since 2012, maize residues from some cropland have been harvested by Huantai farmers for use as cattle feed and the eventual return of the animal manure to cropland. It is possible that the efficiency of SOM accretion through animal manure is higher than that of returning maize straw (Wilhelm et al., 2007), which may result in yet another period of SOM accretion at the regional level with proper dissemination of this technology (Ladha et al., 2011). Similar to northern China, other important grain production region like the Midwest USA also experienced the stage of SOC accumulation, although the practices (residue management, non- or reduced tillage and crop rotation) are different (Ogle et al., 2003; Jelinski and Kucharik, 2009). Adoption of conservation agriculture (NT or minimum tillage) may be another option for SOC sequestration. However, its applicability and efficiency need to be validated through long-term research.

\section{Conclusions}

The study of the impact of agricultural intensification on SOC content and stock was conducted in Huantai County, which is a representative region of northern China. The farmland SOC stock of the whole county increased by more than $50 \%$ over the 3 decades from 1982 to 2011. Among several improved farming practices, the retention of crop residues strongly contributed to the restoration of SOC, but there was no synergistic effect between $\mathrm{N}$ fertilization rate and crop yield on increase in SOC. The SOC content decreased with an increase in mean annual temperature. The temporal change in SOC was significantly influenced by the evolution of the practice of retaining crop residues through implementation of local farming policies. The data support the conclusion that agricultural intensification may both increase crop productivity and enhance some ecosystem services, such as SOC sequestration in croplands of northern China. However, current farming practice (e.g., retention of crop residues) may not always linearly increase SOC over time, indicating a strong need for long-term research. Furthermore, there is also need to explore other options such as the application of manure through integration of crop and animal production. Research on the use of animal manure within the region is a priority, because of its multiple benefits for grain production, the economy and ecosystem services such as SOC sequestration. 
Table 3. Topsoil $(0-20 \mathrm{~cm})$ SOC change from 1980s to 2000s in different agronomic regions of China*.

\begin{tabular}{|c|c|c|c|c|c|c|c|c|}
\hline Region & Site & $\begin{array}{l}\text { Soil type } \\
\text { (FAO) }\end{array}$ & Climate & Period & $\begin{array}{c}\text { SOC } \\
\%\end{array}$ & $\begin{array}{c}\text { SOCD } \\
\mathrm{Mg} \mathrm{ha}^{-1} \mathrm{yr}^{-1}\end{array}$ & $\begin{array}{c}\text { SOCS } \\
\text { Tg yr }^{-1}\end{array}$ & Literature \\
\hline Our study & & & & & 41 & 0.40 & 0.15 & \\
\hline \multirow[t]{5}{*}{ Northern China } & Quzhou & Fluvisols & $\begin{array}{l}\text { Warm, } \\
\text { semi-arid, } \\
\text { temperate } \\
\text { monsoon }\end{array}$ & $1980-2000$ & 31 & & & Liu et al. (2005) \\
\hline & Daxing & Fluvisols & $\begin{array}{l}\text { Warm, } \\
\text { semi-humid, } \\
\text { temperate } \\
\text { monsoon }\end{array}$ & $1981-2000$ & 33 & & & Hu et al. (2006) \\
\hline & Hebei & $\begin{array}{l}\text { Calcaric } \\
\text { Cambisol }\end{array}$ & $\begin{array}{l}\text { Warm, } \\
\text { semi-arid, } \\
\text { temperate } \\
\text { monsoon }\end{array}$ & 1984-2004 & & 0.34 & 2.2 & Xi et al. (2013) \\
\hline & Henan & Fluvisols & $\begin{array}{l}\text { Warm, } \\
\text { semi-humid, } \\
\text { temperate } \\
\text { monsoon }\end{array}$ & 1984-2004 & & 0.32 & 2.8 & Xi et al. (2013) \\
\hline & Luancheng & $\begin{array}{l}\text { Calcaric } \\
\text { Cambisol }\end{array}$ & $\begin{array}{l}\text { Warm, } \\
\text { semi-arid, } \\
\text { temperate } \\
\text { monsoon }\end{array}$ & 1979-2000 & 38 & & & Zhang et al. (2003) \\
\hline \multirow[t]{4}{*}{ Northeast China } & Liaoning & Chernozems & $\begin{array}{l}\text { Semi-humid, } \\
\text { temperate } \\
\text { continental mon- } \\
\text { soon }\end{array}$ & 1984-2004 & & -0.57 & -2.9 & Xi et al. (2010) \\
\hline & Jilin & Albic Luvisols & $\begin{array}{l}\text { Semi-humid, } \\
\text { temperate } \\
\text { monsoon }\end{array}$ & 1985-2005 & & -0.81 & -7.2 & Xi et al. (2010) \\
\hline & Heilongjiang & Phaeozems & $\begin{array}{l}\text { Cold } \\
\text { temperate } \\
\text { monsoon }\end{array}$ & 1986-2006 & & -0.70 & -5.5 & Xi et al. (2010) \\
\hline & Heilongjiang & Phaeozems & $\begin{array}{l}\text { Cold } \\
\text { temperate } \\
\text { monsoon }\end{array}$ & $1982-2002$ & -14 & & & Yu et al. (2003) \\
\hline \multirow[t]{4}{*}{ Northwest China } & Yining & Calciustoll & $\begin{array}{l}\text { Arid } \\
\text { temperate } \\
\text { continental }\end{array}$ & 1981-2001 & -9.3 & & & Hou et al. (2003) \\
\hline & Akesu & $\begin{array}{l}\text { Calcaric } \\
\text { Fluvisols }\end{array}$ & $\begin{array}{l}\text { Arid, warm } \\
\text { temperate } \\
\text { continental } \\
\text { monsoon }\end{array}$ & $1982-2001$ & 10 & & & Li et al. (2002) \\
\hline & Huangshui & $\begin{array}{l}\text { Eutric } \\
\text { Cambisols }\end{array}$ & $\begin{array}{l}\text { Arid, warm } \\
\text { temperate } \\
\text { continental } \\
\text { monsoon }\end{array}$ & $1981-2001$ & 28 & & & Chen et al. (2003) \\
\hline & Zhangye & $\begin{array}{l}\text { Eutric } \\
\text { Cambisols }\end{array}$ & $\begin{array}{l}\text { Arid, warm } \\
\text { temperate } \\
\text { continental } \\
\text { monsoon }\end{array}$ & $1982-2003$ & & 0.2 & & Zhang et al. (2009) \\
\hline
\end{tabular}


Table 3. Continued.

\begin{tabular}{|c|c|c|c|c|c|c|c|c|}
\hline Region & Site & $\begin{array}{l}\text { Soil type } \\
\text { (FAO) }\end{array}$ & Climate & Period & $\begin{array}{c}\text { SOC } \\
\%\end{array}$ & $\begin{array}{c}\text { SOCD } \\
\mathrm{Mg} \mathrm{ha}^{-1} \mathrm{yr}^{-1}\end{array}$ & $\begin{array}{c}\text { SOCS } \\
\text { Tgyr }^{-1}\end{array}$ & Literature \\
\hline \multirow[t]{3}{*}{ East China } & Jiangsu & $\begin{array}{l}\text { Fluvisols/ } \\
\text { Cambisols }\end{array}$ & $\begin{array}{l}\text { Northern } \\
\text { subtropical } \\
\text { humid } \\
\text { monsoon }\end{array}$ & 1980-2000 & 34 & & & Yu et al. (2003) \\
\hline & Jinhua & $\begin{array}{l}\text { Haplic } \\
\text { Alisols }\end{array}$ & $\begin{array}{l}\text { Subtropical } \\
\text { humid } \\
\text { monsoon }\end{array}$ & $1982-2002$ & 2.6 & & & Xie et al. (2003) \\
\hline & Xuzhou & Fluvisols & $\begin{array}{l}\text { Warm, } \\
\text { semi-humid, } \\
\text { temperate } \\
\text { monsoon }\end{array}$ & $1981-2001$ & & $0.1 \sim 0.5$ & & Zhang et al. (2009) \\
\hline \multirow[t]{5}{*}{ Central China } & Hunan & $\begin{array}{l}\text { Haplic } \\
\text { Alisols }\end{array}$ & $\begin{array}{l}\text { Humid, mid- } \\
\text { subtropical } \\
\text { monsoon }\end{array}$ & 1984-2004 & & 0.17 & 0.6 & Xi et al. (2013) \\
\hline & Hubei & $\begin{array}{l}\text { Eutric } \\
\text { Cambisols }\end{array}$ & $\begin{array}{l}\text { Humid, mid- } \\
\text { subtropical } \\
\text { monsoon }\end{array}$ & 1984-2004 & & 0.31 & 1.2 & Xi et al. (2013) \\
\hline & Zhengzhou & Fluvisols & $\begin{array}{l}\text { Warm, } \\
\text { semi-humid, } \\
\text { temperate } \\
\text { monsoon }\end{array}$ & $1982-2003$ & 35 & & & Fu et al. (2004) \\
\hline & Taoyuan & $\begin{array}{l}\text { Haplic } \\
\text { Alisols }\end{array}$ & $\begin{array}{l}\text { Humid, mid- } \\
\text { subtropical } \\
\text { monsoon }\end{array}$ & 1979-2003 & 32 & & & Liu et al. (2006) \\
\hline & Jianghan & $\begin{array}{l}\text { Eutric } \\
\text { Cambisols }\end{array}$ & $\begin{array}{l}\text { Humid, mid- } \\
\text { subtropical } \\
\text { monsoon }\end{array}$ & 1984-2004 & & 0.62 & & Xi et al. (2013) \\
\hline \multirow[t]{5}{*}{ Southern China } & Hainan & $\begin{array}{l}\text { Ferralic } \\
\text { Cambisols }\end{array}$ & $\begin{array}{l}\text { Tropical } \\
\text { monsoon }\end{array}$ & 1984-2004 & & -0.16 & -0.5 & Xi et al. (2013) \\
\hline & Binyang & $\begin{array}{l}\text { Haplic } \\
\text { Acrisols }\end{array}$ & $\begin{array}{l}\text { Tropical } \\
\text { monsoon }\end{array}$ & $1981-2001$ & 19 & & & Liu et al. (2006) \\
\hline & Pixian & $\begin{array}{l}\text { Haplic } \\
\text { Acrisols }\end{array}$ & $\begin{array}{l}\text { Sub-tropical } \\
\text { monsoon }\end{array}$ & 1981-2002 & 9.0 & & & Wei et al. (2004) \\
\hline & Yucheng & $\begin{array}{l}\text { Haplic } \\
\text { Acrisols }\end{array}$ & $\begin{array}{l}\text { Sub-tropical } \\
\text { monsoon }\end{array}$ & $1981-2002$ & 19 & & & Hu et al. (2004) \\
\hline & Meitan & $\begin{array}{l}\text { Haplic } \\
\text { Acrisols }\end{array}$ & $\begin{array}{l}\text { Sub-tropical } \\
\text { monsoon }\end{array}$ & $1980-2001$ & 67 & & & Ding et al. (2002) \\
\hline
\end{tabular}

* Only the literature with more than 20 years of experimental interval and more than 30 observation/sampling points were included. 
Author contributions. Fanqiao Meng, Wenliang Wu and Yan Liao designed the experiments and Yan Liao carried them out. Yan Liao and Pete Smith performed the calculations and data analysis. Yan Liao, Fanqiao Meng, Pete Smith and Rattan Lal prepared the manuscript with contributions from all co-authors.

Acknowledgements. This research was supported by National Natural Science Foundation of China (no. 31370527 and 31261140367) and the National Science and Technology Support Program of China (no. 2012BAD14B01-2). The authors gratefully thank the Huantai Agricultural Station for providing of the Soil Fertility Survey data. We also thank Zheng Liang from China Agricultural University for the soil sampling and analysis in 2011. Thanks are extended to Jessica Bellarby for helpful discussion and suggestions.

Edited by: Y. Kuzyakov

\section{References}

Alvarez, R.: A review of nitrogen fertilizer and conservation tillage effects on soil organic carbon storage, Soil Use Manage., 21, 3852, 2005.

Benbi, D. K. and Brar, J. S.: A 25-year record of carbon sequestration and soil properties in intensive agriculture, Agr. Sustain. Develop., 29, 257-265, 2009.

Chen, Z., Xue, Q., and Zhang, R.: Farmland soil nutrients evaluation and analysis in Huangshui, Qinghai Sci. Technol., 2, 29-32, 2003.

De Bruijn, A. M. G., Calanca, P., Ammann, C., and Fuhrer, J.: Differential long-term effects of climate change and management on stocks and distribution of soil organic carbon in productive grasslands, Biogeosciences, 9, 1997-2012, doi:10.5194/bg9-1997-2012, 2012.

Ding, Q.: Soil fertility change in Xinshi, Meitan County, Till. Cultivat., 3, 36-37, 2002.

Eve, M. D., Sperow, M., Paustian, K., and Follett, R. F.: Nationalscale estimation of changes in soil carbon stocks on agricultural lands, Environ. Pollut., 116, 431-438, 2002.

Firbank, L. G., Elliott, J., Drake, B., Cao, Y., and Gooday, R.: Evidence of sustainable intensification among British farms, Agricult. Ecosyst. Environ., 173, 58-65, 2013.

Freibauer, A., Rounsevell, M. D. A., Smith, P., and Verhagen, J.: Carbon sequestration in the agricultural soils of Europe, Geoderma, 122, 1-23, 2004.

Fu, Q., Wu, K., and Lv, Q.: Soil fertility analysis and management in Zhengzhou city, Hebei Agricult. Res., 8, 53-56, 2004.

Hou, H., Zhang, J., and Luo, X.: Soil nutrients change and fertilization measures in Yining, Xinjiang Agricult. Sci. Technol., 6, 21-24, 2003.

$\mathrm{Hu}$, Y., Deng, S., and Zhang, S.: Soil nutrients variation and sustainable land use in Yucheng, Soil Water Conservat. Res., 18, 124-128, 2004.

Huang, Y., Sun, W., Zhang, W., and Yu, Y.: Changes in soil organic carbon of terrestrial ecosystems in China: A mini-review, Sci. China-Life Sci., 53, 766-775, 2010.

Jankauskas, B., Slepetiene, A., Jankauskiene, G., Fullen, M. A., and Booth, C. A.: A comparative study of analytical methodologies to determine the soil organic matter content of Lithuanian Eutric Albeluvisols, Geoderma, 136, 763-773, 2006.

Jelinski, N. A. and Kucharik, C. J.: Land-use effects on soil carbon and nitrogen on a US midwestern floodplain, Soil Sci. Soc. Am. J., 73, 217-225, 2009.

Johnson, J. F., Allmaras, R. R., and Reicosky, D. C.: Estimating source carbon from crop residues, roots and rhizodeposits using the national grain-yield database, Agron. J., 98, 622-636, 2006.

Khan, S. A., Mulvaney, R. L., Ellsworth, T. R., and Boast, C. W.: The myth of nitrogen fertilization for soil carbon sequestration, J. Environ. Qual., 36, 1821-1832, 2007.

Kong, X., Lal, R., Li, B., Liu, H., Li, K., Feng, G., Zhang, Q., and Zhang, B.: Fertilizer intensification and its impacts in China's HHH Plains, in: Advances in Agronomy, Vol 125, edited by: Sparks, D. L., Advances in Agronomy, 2014.

Kucharik, C. J., Brye, K. R., Norman, J. M., Foley, J. A., Gower, S. T., and Bundy, L. G.: Measurements and modeling of carbon and nitrogen cycling in agroecosystems of southern Wisconsin: Potential for SOC sequestration during the next 50 years, Ecosystems, 4, 237-258, 2001.

Ladha, J. K., Reddy, C. K., Padre, A. T., and van Kessel, C.: Role of nitrogen fertilization in sustaining organic matter in cultivated soils, J. Environ. Qual., 40, 1756-1766, 2011.

Lal, R.: Soil carbon sequestration in China through agricultural intensification, and restoration of degraded and desertified ecosystems, Land Degrad. Develop., 13, 469-478, 2002.

Lal, R.: Food security in a changing climate, Ecohydrol. Hydrobiol., 13, 8-21, 2013.

Li, R., Cao, M., and Dai, L.: Fertilization management of high density cotton soil in Akesu, Xinjiang Agricul. Sci. Technol., 6, 14$15,2002$.

Liu, C., Lu, M., Cui, J., Li, B., and Fang, C.: Effects of straw carbon input on carbon dynamics in agricultural soils: A meta-analysis, Glob. Change Biol., 20, 1366-1381, 2014.

Liu, S., Huang, D., Wu, J., Huang, M., Xiao, H., Song, B., and Su, Y.: Nitrogen content and its distribution in typical red soil of hilly area, Plant Nutrit. Fertil. Res., 12, 12-17, 2006.

Liu, Y., Yu, Z., Zhang, F., Song, C., and Liu, Y.: Dynamic change of soil organic matter and its affecting factors at county level, Plant Nutrit. Fertil. Sci., 11, 294-301, 2005.

Ludwig, B., Geisseler, D., Michel, K., Joergensen, R. G., Schulz, E., Merbach, I., Raupp, J., Rauber, R., Hu, K., Niu, L., and Liu, $\mathrm{X}$.: Effects of fertilization and soil management on crop yields and carbon stabilization in soils. A review, Agron. Sustain. Dev., 31, 361-372, 2011.

Matson, P. A., Parton, W. J., Power, A., and Swift, M.: Agricultural intensification and ecosystem properties, Science, 277, 504-509, 1997.

Miao, Y., Stewart, B. A., and Zhang, F.: Long-term experiments for sustainable nutrient management in China. A review, Agron. Sustain. Dev., 31, 397-414, 2011.

Mulvaney, R. L., Khan, S. A., and Ellsworth, T. R.: Synthetic nitrogen fertilizers deplete soil nitrogen: A global dilemma for sustainable cereal production, J. Environ. Qual., 38, 2295-2314, 2009.

National Bureau of Statistics of China (NBSC): China Statistical Yearbook 2013, China Statistics Press, Beijing, 2014.

Ogle, S. M., Jay Breidt, F., Eve, M. D., and Paustian, K.: Uncertainty in estimating land use and management impacts on soil 
organic carbon storage for US agricultural lands between 1982 and 1997, Global Change Biol., 9, 1521-1542, 2003.

Page, A. L., Miller, R. H., and Keeney, D. R.: Total carbon, organic carbon, and organic matter, Methods Soil Anal., 2, 539579, 1982.

Pan, G., Smith, P., and Pan, W.: The role of soil organic matter in maintaining the productivity and yield stability of cereals in China, Agriculture, Ecosys. Environ., 129, 344-348, 2009.

Paustian, K., Andrén, O., Janzen, H. H., Lal, R., Smith, P., Tian, G., Tiessen, H., Noordwijk, M. V., and Woomer, P. L.: Agricultural soils as a sink to mitigate $\mathrm{CO}_{2}$ emissions, Soil Use Manage., 13, 230-244, 1997.

Post, W. M., Emanuel, W. R., Zinke, P. J., and Stangenberger, A. G.: Soil carbon pools and world life zones, Nature, 298, 156159,1982

Qiu, J., Wang, L., Li, H., Tang, H., Li, C., and Ranst, E.: Modeling the impacts of soil organic carbon content of croplands on crop yields in China, Sci. Agricul. Sinicia, 42, 154-161, 2009.

Reijneveld, A., van Wensem, J., and Oenema, O.: Soil organic carbon contents of agricultural land in the Netherlands between 1984 and 2004, Geoderma, 152, 231-238, 2009.

Robertson, G. P. and Vitousek, P. M.: Nitrogen in agriculture: Balancing the cost of an essential resource, Ann. Rev. Environ. Resour., 34, 97-125, 2009.

Sainju, U. M., Caesar-TonThat, T., and Jabro, J. D.: Carbon and nitrogen fractions in dryland soil aggregates affected by longterm tillage and cropping sequence, Soil Sci. Soc. Am. J., 73, 1488-1495, 2009.

Shi, Y., Wu, W., Meng, F., Zhang, Z., Zheng, L., and Wang, D.: Integrated management practices significantly affect $\mathrm{N}_{2} \mathrm{O}$ emissions and wheat-maize production at field scale in the North China Plain, Nutr. Cy. Agroecosys., 95, 203-218, 2013.

Smith, P., Andrén, O., Karlsson, T., Perälä, P., Regina, K., Rounsevell, M., and Wesemael, B.: Carbon sequestration potential in European croplands has been overestimated, Glob. Change Biol., 11, 2153-2163, 2005.

Smith, P., Davies, C. A., Ogle, S., Zanchi, G., Bellarby, J., Bird, N., Boddey, R. M., McNamara, N. P., Powlson, D., Cowie, A., van Noordwijk, M., Davis, S. C., Richter, D. d. B., Kryzanowski, L., van Wijk, M. T., Stuart, J., Kirton, A., Eggar, D., Newton-Cross, G., Adhya, T. K., and Braimoh, A. K.: Towards an integrated global framework to assess the impacts of land use and management change on soil carbon: current capability and future vision, Glob. Change Biol., 18, 2089-2101, 2012.

Song, G., Li, L., Pan, G., and Zhang, Q.: Topsoil organic carbon storage of China and its loss by cultivation, Biogeochemistry, 74, 47-62, 2005.
Srinivasarao, C., Lal, R., Kundu, S., Babu, M., Venkateswarlu, B., and Singh, A. K.: Soil carbon sequestration in rainfed production systems in the semiarid tropics of India, Science of The Total Environment, 487, 587-603, 2014.

Stockmann, U., Adams, M. A., Crawford, J. W., Field, D. J., Henakaarchchi, N., Jenkins, M., Minasny, B., McBratney, A. B., de Courcelles, V. d. R., Singh, K., Wheeler, I., Abbott, L., Angers, D. A., Baldock, J., Bird, M., Brookes, P. C., Chenu, C., Jastrowh, J. D., Lal, R., Lehmann, J., O’Donnell, A. G., Parton, W. J., Whitehead, D., and Zimmermann, M.: The knowns, known unknowns and unknowns of sequestration of soil organic carbon, Agricul. Ecosys. Environ., 164, 80-99, 2013.

Triberti, L., Nastri, A., Giordani, G., Comellini, F., Baldoni, G., and Toderi, G.: Can mineral and organic fertilization help sequestrate carbon dioxide in cropland?, Europ. J. Agron., 29, 13-20, 2008.

Vanden Bygaart, A. J., Gregorich, E. G., Angers, D. A., and Stoklas, U. F.: Uncertainty analysis of soil organic carbon stock change in Canadian grain field from 1991 to 2001, Glob. Change Biol., 10, 984-994, 2004.

Wang, P., Qin, F., Cai, P., Meng, F., Zhang.: Comparison of Acidification and Soil Organic Carbon Determination for Semihumid Soils in North China, Chinese J. Soil Sci., 45, 880-888, 2014.

Wang, Y. and Cao, S.: Carbon sequestration may have negative impacts on ecosystem health, Environ. Sci. Technol., 45, 17591760, 2011.

Wei, S., Zhang, S., and Deng, L.: Soil organic matter change in Pixian, Sichuan province, Chinese J. Soil Sci., 35, 261-263, 2004.

Wilhelm, W. W., Johnson, J. M. F., Karlen, D. L., and Lightle, D. T.: Corn stover to sustain soil organic carbon further constrains biomass supply, Agron. J., 99, 1665-1667, 2007.

Xi, X., Yang, Z., Cui, Y., Sun, S., Yu, C., and Li, M.: A study of soil carbon distribution and change in Northeast Plain, Earth Sci. Front., 17, 213-221, 2010.

Xi, X., Li, M., Zhang, X., Zhang, Y., Zhang, D., Zhang, J., Dou, L., and Yang, Y.: Research on soil organic carbon distribution and change trend in middle-east plain and its vicinity in China, Earth Sci. Front., 20, 154-165, 2013.

Xie, J.: Soil nutrients sampling and analysis in Paddy soil of Zhejiang Province, Zhejiang Agricul. Res., 6, 327-329, 2003.

Yu, H., Huang, J., and Scott, R.: Soil fertility change in eastern part of China, Geogr. Res., 22, 380-388, 2003.

Zhang, W. J., Wang, X. J., Xu, M. G., Huang, S. M., Liu, H., and Peng, C.: Soil organic carbon dynamics under long-term fertilizations in arable land of northern China, Biogeosciences, 7, 409-425, doi:10.5194/bg-7-409-2010, 2010.

Zhang, Y., Hu, C., and Mao, R.: Soil nutrients evaluation and management in the farmland of Luancheng, Hebei Province, Dry. Agricul. Res., 21, 68-72, 2003. 